The Child Penalty -

What about Job Amenities?

Christina Felfe

November 2008 Discussion Paper no. 2008-22 
Editor:

Publisher:
Prof. Jörg Baumberger

University of St. Gallen

Department of Economics

Bodanstr. 1

$\mathrm{CH}-9000$ St. Gallen

Phone +4171 2242241

Fax $\quad+41712242885$

Email joerg.baumberger@unisg.ch

Department of Economics

University of St. Gallen

Varnbüelstrasse 19

$\mathrm{CH}-9000$ St. Gallen

Phone $\quad+41712242325$

Fax $\quad+41712242298$

http://www.vwa.unisg.ch 


\title{
The Child Penalty - \\ What about Job Amenities?
}

\author{
Christina Felfe
}

Author's address:

Christina Felfe, PhD

Swiss Institute for Empirical Economic Researc

Varnbüelstr. 14

9000 St. Gallen

Phone $\quad+41712242329$

Fax $\quad+41712242302$

Email Christina.felfe@unisg.ch

Website

http://www.sew.unisg.ch/org/sew/web.nsf/wwwPubPersonGer/

Felfe+Christina?opendocument 


\begin{abstract}
Women with children tend to earn lower hourly wages than women without children - a shortfall known as the 'child penalty'. While many studies provide evidence for this empirical fact and explore several hypotheses about its causes, the impact of motherhood on job dimensions other than wages has scarcely been investigated. In order to assess changes in women's jobs around the time of first childbirth, I use data from the German Socio-Economic Panel and apply an event study analysis. The results show not only a significant change in women's hourly wages $(-19 \%)$ once becoming mothers, but also in other non-pecuniary job characteristics, such as working hours (-15 hours), night work $(-6 \%)$, work in the evening hours $(-8 \%)$, stress $(-10 \%)$, physical requirements $(4 \%)$, hazards $(-3 \%)$ and distance to the workplace $(-1 \mathrm{~km})$. In order to assess the hypothesis that mothers might substitute wages for non-wage benefits, I additionally estimate a hedonic wage regression. The results suggest that mothers trade pecuniary for non-pecuniary job characteristics and hence, that part of the child penalty $(8.2 \%)$ might be interpreted as a compensating wage differential.
\end{abstract}

\title{
Keywords
}

Penalty, Compensating Wage Differentials; Sample Selection in Panel Data

\section{JEL Classification}

$\mathrm{J} 31 ; \mathrm{J} 33$ 


\title{
The Child Penalty - What about Job Amenities?
}

\author{
Christina Felfe \\ University of St. Gallen
}

October 2008

\begin{abstract}
Women with children tend to earn lower wages than women without children - a shortfall known as the 'child penalty'. While many studies provide evidence for this empirical fact and explore several hypotheses about its causes, the impact of motherhood on job dimensions other than wages has scarcely been investigated. In order to assess changes in women's jobs around the time of first childbirth, I use data from the German Socio-Economic Panel and apply an event study analysis corrected for sample selection into labor force. The results show not only a significant change in women's wages $(-19 \%)$ once becoming mothers, but also in other non-pecuniary job characteristics, such as working hours (-15 hours), night work (-6\%), work in the evening hours $(-8 \%)$, stress $(-10 \%)$, physical requirements $(4 \%)$, hazards $(-3 \%)$ and distance to the workplace $(-1 \mathrm{~km})$. In order to assess the hypothesis that mothers might substitute wages for non-wage benefits, I additionally estimate a hedonic wage regression. The results suggest that mothers trade pecuniary for non-pecuniary job characteristics and hence, that part of the child penalty ( $8 \%$ ) might be interpreted as a compensating wage differential.
\end{abstract}

JEL-Code: J31; J31; J33

Keywords: Child Penalty, Compensating Wage Differentials; Sample Selection in Panel Data 


\section{Introduction}

The stylized fact that working mothers tend to earn less than childless women seems to be well established in the economic literature and is called the 'child penalty' or the 'motherhood wage gap'. Several researchers have found raw motherhood wage gaps of almost $20 \%$ in the US, up to $20 \%$ in Germany and $13 \%$ in the UK. ${ }^{1}$ The following hypotheses about its sources have been investigated: unobserved heterogeneity between women with and without children, employer discrimination, loss in human capital during maternity leave, different work schedules, and choice of sector or job type. Yet so far, the hypothesis that the jobs of women with and without children may differ with respect to certain non-pecuniary characteristics has not been fully explored: ${ }^{2}$ Once having a child, women might change the criteria according to which they make their job choice. If a better paid job does not offer family-friendly conditions, a mother may decide to work at a lower paid job with better features. Hence, a mother might sacrifice income to avoid inconvenient job characteristics, referred to as disamenities.

This study contributes to the literature on the child penalty by providing evidence for changes in women's jobs around the time of first childbirth, not only with respect to wages but also to non-pecuniary job features. A simultaneous drop in wages and non-wage job characteristics is suggestive of a compensating wage differential (CWD) story; i.e. lower wages for mothers might reflect their aversion to disamenities. A hedonic wage regression sheds additional light on the idea that mothers might trade wages for non-wage job characteristics.

The German Socio-Economic Panel (GSOEP, 1984-2005) represents a particularly suitable dataset for looking at changes in women's jobs around motherhood. The dataset provides detailed information about personal attributes and job characteristics, with attention

\footnotetext{
${ }^{1}$ See Waldfogel (1997), Waldfogel and Harkness (1999) and Ejrnaes and Kunze (2004).

${ }^{2}$ To my knowledge, no study explores a broad range of disamenities. Existing studies have either looked only at part-time jobs (Waldfogel, 1997; Bratti, del Boca and Vuri, 2004), health care coverage (Amuedo-Dorantes and Kimmel, 2008) or the public sector (Nielsen, Simonsen and Verner, 2001) separately.
} 
given to the wage and, particularly, the non-wage aspects of jobs. The longitudinal nature of the data allows the observation of women during their fertile ages, defined as age 16 to 46 . As a result, not only can we compare the jobs of mothers and non-mothers, but also the jobs of mothers before and after they have had their first child. Thus, it is possible to estimate changes in all job characteristics around the time of the first childbirth and to set up a relation of wages and non-wage aspects of mothers' jobs.

The methodology used in this study is an event-study analysis. Unlike previous studies, I estimate not only changes in wages, but also in turnover and non-pecuniary job characteristics and additionally correct for the fact that only working mothers are included in the sample (Wooldridge, 1995; Jimenez, 2006). I find evidence for simultaneous changes in wages $(-19 \%)$ and non-wage aspects, such as working hours (-15 hours), night work (-6\%), work in the evenings $(-8 \%)$, stress $(-10 \%)$, physical requirements $(4 \%)$, hazards $(-3 \%)$ and commuting $(-1 \mathrm{~km})$. In order to give some support to the idea that mothers might trade wages for family friendly characteristics, I additionally estimate a hedonic wage regression. The results show that women who accept certain disamenities are compensated by significantly higher wages ( $2 \%$ for stress, $3 \%$ for hazards and $1 \%$ for $10 \mathrm{~km}$ more distance). This finding, and the decrease in the child penalty (-10\%), suggests a CWD scenario; the lower wages of mothers seem to reflect their preferences for non-wage aspects of jobs.

The study is structured as follows. In section 2, I briefly present previous research on the child penalty. The data and methodology are described in Section 3. Section 4 reports the regression results and Section 5 concludes.

\section{Background on the Child Penalty}

The negative impact of motherhood on individual wages has been well studied. The most common approach to analyzing the wage effect of having children has been to estimate the child penalty, i.e. to compare the wages of women before and after giving birth to their 
first child while controlling for observed characteristics. The family gap in the US and UK, according to Waldfogel (1994), is large and persistent. Among young women, mothers' wages lag 20 percentage points behind those of comparable non-mothers. Harkness and Waldfogel (1999) find some evidence of the child penalty in several industrialized countries, such as Australia, Canada, Germany, Finland and Sweden. They find that different institutions in these countries lead to a wide variation in the magnitude of the wage gap. On the one hand, a larger motherhood wage gap is positively correlated with the gender gap, while on the other hand it is negatively correlated with women's labor market participation.

Several theoretical explanations for the child penalty are offered in the socio-economic literature. The first hypothesis is that women differ with respect to abilities and preferences. Both characteristics may be correlated with fertility and are usually unobserved. Previous studies deal with this issue of unobserved heterogeneity by applying a fixed-effect methodology. Using this approach Waldfogel (1997) cannot detect any unobserved payrelevant differences between mothers and non-mothers in the US. Lundberg and Rose (2000), however, find a wage gap of $9 \%$ even before the first birth. Kunze and Ejrnaes (2004) confirm the drop in wages prior to the first birth for Germany (5\%). This early dip in wages might indicate unobserved heterogeneity between mothers and non-mothers.

A second hypothesis claims that the presence of children might limit mothers' mobility and hence, restrict mothers in their job choice. Owing to higher job-search costs, mothers might maintain poor job matches; thus, the quality of their job match improves only slowly and lower earnings follow as a consequence. Conversely, Waldfogel (1998a) and Phipps et al. (2001) find that maintaining the same job position after maternity leave decreases the child penalty. Returning to the same employer acts as an insurance against income loss.

Another possibility is that employers assume differences in productivity and flexibility and thus discriminate against mothers. The hypothesis of discrimination was first suggested 
by Becker (1985). Discrimination means that given the same individual attributes, employers treat mothers and non-mothers differently for reasons not related to productivity. Employer prejudices could include the idea that mothers are less productive since they have less time and can put less effort into their job. However, it is hard to prove discrimination. Phipps et al. (2001) include the hours spent on unpaid work in their estimation. This approach to testing the discrimination theory reveals that the child penalty declines, but it still remains significant.

Further hypotheses rest upon differences in accumulated human capital. One prominent supposition is that maternity leave interrupts the labor market career and leads, like all kinds of career interruptions, to a loss in work experience and thus to a depreciation of human capital (Mincer and Polachek, 1974). In the US and the UK, Waldfogel (1998b) finds evidence in support of a decrease in wages due to maternity leave. This wage reduction following a career interruption has been confirmed for German men and women (Beblo and Wolf, 2002). Despite the generous German parental leave system, the depreciation of human capital as a result of maternity leave is even higher than that of unemployment (Kunze, 2002).

Alongside career interruptions, periods of part-time work also cause depreciation in human capital. Mothers might be particularly likely to take advantage of part-time work since it promotes the combination of work and family. Traditional wage estimations that do not control for part-time periods might underestimate the return to work experience. Recent studies substitute potential work experience with actual work experience, taking into account the duration of non-employment and part-time spells. Periods of part-time work are relevant for explaining the child penalty in the US and the UK (see Waldfogel, 1997; Joshi et al., 1999). Nevertheless, there is still evidence of the family gap for women employed full-time. Beblo and Wolf (2000) include in their estimations not only part-time periods of work but also the timing of career interruptions. Using German data, their estimation results suggest that deviations from full-time employment are penalized by significant wage cuts. Additionally, the wage rate falls even more if the period of career discontinuity is postponed. 
Previous studies have related the motherhood wage gap also to sectoral or occupational segregation. Sectors or types of jobs held primarily by mothers are, in general, lower paid. They might however compensate their workers for the loss in income by a more family-friendly working environment. This might explain the child penalty to some degree. Nielsen et al. (2001) address the issue of sector choice. Using a model where the choice between private and public sector is endogenous, they find only a small wage effect of career interruptions in the public sector and no effects in the private one. Amuedo-Dorantes and Kimmel (2008) investigate the possibility that mothers select into jobs offering employmentbased health insurance and find that the motherhood wage gap appears to originate, at least in part, from a negative CWD for the presence of health insurance. Beblo et al. (2004) account for the differences among sectors by matching comparable mothers and non-mothers working for the same firm. They confirm a significant child penalty even within firms.

The last two hypotheses address to some extent the focus of this study: once becoming a mother, women might change the criteria according to which they make their job choice, and thus, they might sacrifice income to avoid job-related disamenities. Yet, so far, only the general idea that mothers sort into jobs offering a family friendly atmosphere and a few job aspects, namely part-time or health care benefits, have been investigated.

This study adds to the literature by considering a broader range of disamenities and determining the ones that seem to be avoided by mothers. Using a longitudinal dataset (GSOEP), the prevalence of several non-pecuniary job characteristics following the first childbirth can be revealed. Including these job features in the wage regression provides evidence that mothers trade pecuniary against non-pecuniary job characteristics and hence is suggestive for a CWD story.

The following section describes the data and explains the estimation methodology. 


\section{Data and Methodology}

The dataset used is the German Socio-Economic Panel (GSOEP), which is an annually repeated survey of Germans and foreigners in West and East Germany (1984-2005). ${ }^{3}$ The longitudinal nature of the data allows the observation of mothers for the years around first childbirth. Thus, not only can we compare the jobs of women with and without children, but also the jobs of women before and after they become mothers. Another feature that makes the GSOEP especially suitable for our purposes is that it provides detailed annual information on pecuniary and non-pecuniary job characteristics, which allows me to analyze the relationship between these two dimensions of women's jobs.

The sample includes all women of fertile age, defined as age 16 to 46 . It consists of 2,814 individuals, 1,989 of whom are mothers (defined as all women who have a baby prior to 2005) and 895 of whom are non-mothers as of $2005 .^{4}$ This definition, however, does not exclude the possibility that a childless woman might have children after 2005 .

In order to assess the hypothesis that mothers might substitute wages with non-wage job aspects, I pursue the following approach. I first investigate whether not only wages but also other non-wage job aspects change around the time of first childbirth and, consequently, the loss of wages may be compensated by a simultaneous drop in disamenities. For this purpose, I use an event study analysis which allows me to examine the effects of motherhood on wages, turnover and a variety of non-pecuniary job characteristics separately (see Section 3.1.). When performing this analysis, one has to bear in mind that women, particularly when becoming a mother, are likely to drop out of the labor market. Hence, the fact that my sample contains only working women could lead to sample selection bias, which is a problem I

\footnotetext{
${ }^{3}$ In 2005 the GSOEP provided information about more than 12,000 households consisting of approximately 24,000 individuals.

${ }^{4}$ An alternative dataset includes only the women who did get their first baby between 1985 and 2004. Taking into account as well attrition, this dataset guarantees that women are observed (at least one period) before and after the event of first birth. I decided to use the dataset including all women that got their first baby as of 2005 due to the following reasons: first, I cannot exclude the possibility that the timing of first birth might be endogenous and second, the larger sample size of the first dataset leads to more significant results. In any case the results using the alternative dataset are available on request.
} 
address in Section 3.1.2. In a second step, I perform a hedonic wage regression which allows me to shed some light on the hypothesis that mothers might trade wages for non-wage job aspects (see Section 3.2.).

\section{1. Empirical test of changes in job characteristics around first childbirth}

\subsubsection{Event study}

As noted above, the first step involved in this analysis is to show that the jobs of women before and after first childbirth differ not only in wages but also in other non-wage aspects. This comparison is done in the form of an event study analysis, a method used to investigate if a particular event influences some outcome - here if motherhood affects job characteristics. The basic model is the following:

$$
\mathrm{Y}_{\mathrm{it}}=\beta_{1} * \operatorname{Pre}_{\mathrm{it}}+\beta_{2} * \operatorname{Birth}_{1 \mathrm{it}}+\beta_{3} * \operatorname{Post}_{\mathrm{it}}+\delta^{*} \mathrm{X}_{\mathrm{it}}+\mathrm{a}_{\mathrm{i}}+\mathrm{u}_{\mathrm{it}}
$$

where $Y_{\text {it }}$ represents the wage, job turnover and a variety of non-pecuniary job characteristics, described below. To compare the periods before and after first childbirth, the following three dummies are introduced: Birth $1_{\text {it }}$ represents the year of the first childbirth, Pre $1_{\text {it }}$ all years prior, and Post $1_{\text {it }}$ all years afterwards. ${ }^{5}$ An example might help to illustrate the definition of the three dummies as follows: if a mother gives birth to her first child in 1990, the year 1990 will be defined as the year of birth. ${ }^{6}$ According to the definition given above, all years from 1984 to 1989 are included in the Pre1 dummy and all years from 1991 onward are captured by the Post1 dummy. The Pre1 dummy is introduced in order to capture the heterogeneity between mothers and non-mothers that may already exist before the time of first childbirth. The difference between the coefficients of the Post1 and Pre1 dummy $\left(\beta_{3}-\beta_{1}\right)$ represents then the child penalty, i.e. it compares how the job of a woman changes after the first childbirth in comparison to before.

\footnotetext{
${ }^{5}$ For a non-mother all three dummies (Birth1, Pre1 and Post1) take the value zero.

${ }^{6}$ In order to distinguish between births that are early and late in the year, I define year $\mathrm{t}$ as birth year if the child is born before September of year $t$, and respectively year $t+1$ as the birth year if the birth is between September and December of year $t$.
} 
Table 1 provides an overview of all job features investigated in the event study: first, the wage is included as the logarithm of the real gross wage rate $;^{7}$ second, the presence of job turnover is considered first in general and then as a change of the employer and as a change within a firm; and third, several non-pecuniary job characteristics are selected according to the literature on CWD, for example Rosen (1986) and Villanueva (2007). Thus, in this study, I consider aspects of the working time, the workload and flexibility.

Time is a scarce resource for mothers since they have to allocate it between a job and family. Therefore, it can be assumed that the marginal utility of time increases when having a child. This may lead to a reallocation of the hours spent on the job and on housework. Thus, weekly working hours are considered in the analysis and included in the model as the number of hours a woman is actually working, i.e. the contracted working hours plus any overtime. Furthermore, different aspects of the schedule are taken into consideration such as work in the evening, at night or in rotating shifts. I also investigate whether the job of a woman allows a certain degree of flexibility. One aspect is a flexible working schedule, i.e. if a woman can decide her working hours as she sees fit. Another feature determining the flexibility of a job is the possibility to work from home. The fixed costs of traveling to work may play a role in job decisions as well; thus, the distance to the workplace, measured in kilometers, is evaluated. Jobs also differ in the heaviness of the workload, which is measured by stress, physical demand and working conditions (such as dust, dirt, etc.). The workload may be relevant for a mother since she has to face a double load of work on the job and at home. It is clear that these variables are highly subjective and may be evaluated differently by everyone - in particular by mothers and non-mothers.

According to equation (1), each of the above-described variables is then regressed (separately) on the dummies Pre1, Birth1 and Post1 as well as on a set of control variables,

\footnotetext{
${ }^{7}$ The $\ln$ of the real gross wage rate is calculated taking into account contracted working hours. The advantage of taking contracted hours instead of actual working hours is that it is an objective measure and does not create as many outliers. Additionally, I limit the observations of real wage rates to values between the $5^{\text {th }}$ and the $95^{\text {th }}$ percentile.
} 
such as a dummy for having a partner, age, age squared, education, origin, and a set of dummies for the years from 1984 to 2005 , all represented by the variable $\mathrm{X}_{\mathrm{it}}$. Using linear fixed-effect models allows me then to measure the changes in certain job characteristics around the time of first childbirth while accounting for unobserved heterogeneity, such as preferences for job characteristics and family life as well as the subjectivity in the evaluation of the different job characteristics.

As mentioned above, women, especially mothers, often do not continuously participate in the labor market. Hence, a sample selection problem might arise. The next subsection suggests a possible test and correction method for this potential source of bias.

\subsubsection{Sample selection and labour force participation}

As empirical evidence and past research confirm, there is still a strong negative impact of motherhood on labor force participation (LFP). We can observe this impact in our sample, which includes all women aged between 16 and 46, who have been employed at least at some point between 1984 and 2005 and who have either had a baby before 2005 or not had a baby as of 2005. An overview of LFP around the first childbirth can be found in Table 2 .

A high percentage of women drop out of the labor force when having a child. Although before the first childbirth LFP is continuously high (around 80\%), it falls dramatically in the year of the first childbirth (to $34 \%$ ) and even more so the year after $(25 \%)$. Some mothers decided to return to work, but this return was only observed gradually: after two years maternal employment was 36\%; after three years it was higher than $40 \%$ and after six years it rose to more than $50 \%$. Yet even if some mothers return to the labor market, others may never return once having children - even when the first child was an adult less than $65 \%$ of the mothers worked, while more than $80 \%$ did prior to the first child.

As previously mentioned, the fact that women drop out of the labor force disproportionately when becoming a mother indicates self-selection of mothers. It is well known that failure to account for sample selection can lead to inconsistent estimates. Linear 
panel data models, which take care of unobserved, individual and permanent heterogeneity by adding a fixed effect, do not eliminate sample selection bias. ${ }^{8}$ One of the first approaches to assessing sample selection in panel data was suggested by Wooldridge (1995). ${ }^{9}$

As the LFP decision might be correlated with motherhood, I carry out the test for endogeneity of self-selection by Wooldridge (1995), adjusted according to suggestions by Jimenez (2006), and apply, when necessary, the correction method as follows:

1. First, the probability of LFP is estimated separately for each year, i.e. using a probit estimation method, for each year LFP is regressed on age, age squared, education, year dummies and, serving as exclusion restrictions, partner's income and mothers' satisfaction with the income and the household: ${ }^{10}$

$$
\mathrm{P}\left(\text { Working }_{\mathrm{it}}=1\right)=\gamma^{*} \mathrm{Z}_{\mathrm{it}}+\mathrm{v}_{\mathrm{it}}
$$

Using the results of the probit estimation, the inverse mills ratio $\lambda\left(\gamma^{*} Z_{\mathrm{it}}\right)$ can be calculated for each individual in every year.

2. A fixed effect estimation is applied to equation (1), including the inverse mills ratio as a further control and using only the observations of the sample of working women:

$$
\mathrm{Y}_{\mathrm{it}}=\beta_{1} * \operatorname{Pre}_{\mathrm{it}}+\beta_{2} * \operatorname{Birth}_{\mathrm{it}}+\beta_{3} * \operatorname{Post}_{\mathrm{it}}+\rho^{*} \lambda\left(\gamma^{*} \mathrm{Z}_{\mathrm{it}}\right)+\delta^{*} \mathrm{X}_{\mathrm{it}}+\mathrm{a}_{\mathrm{i}}+\mathrm{u}_{\mathrm{it}}
$$

Using a t-statistic, a test can be run for the null hypothesis of no sample selection, i.e. if the coefficient of the inverse mills ratio is not significantly different from $0\left(\mathrm{H}_{0}: \rho=0\right)$. In

\footnotetext{
${ }^{8}$ This is because the sample selection effect is generally an unknown nonlinear function of both the observed time-varying regressors and the unobservable individual effects of the selection equation, and is thus not constant over time.

${ }^{9}$ Further estimators correcting for sample selection have been proposed by Ekaterina Kyriazidou (1997) and Maria Rochina-Barrachina (1999). Dustmann and Rochina-Barrachina (2000) and Wooldridge and Semykina (2005) suggest further extensions to these methods.

${ }^{10}$ I carry out regressions for two different specification of the reduced form: on the one hand I introduce as proposed by Wooldridge, the above-mentioned control variables for all years. This increases the explanative power of the probit regression but leads to a reduction of the sample since not for many individuals we have observations for all years. On the other hand, I follow the suggestion by Jimenez (2006) and use control variables only for the same years, which has the opposite advantages. The results are similar, so I will present for simplicity the results applying the specification suggested by Jimenez (2006).
} 
the case where the null hypothesis can be rejected, it is necessary to keep the estimated inverse mills ratio in the regression equation to yield consistent estimates.

\subsection{Hedonic wage regressions}

Once the job features that are avoided by mothers are identified, the next step is to measure how much income a mother must sacrifice to avoid unpleasant working conditions, i.e. to test the hypothesis that the relatively lower wages of mothers reflect a CWD story.

The theory of CWD, first suggested by Adam Smith (1776) and formalized by Rosen (1986), asserts that jobs are bundles of wages and non-wage aspects and that the loss in one dimension has to be compensated by a gain in the other. The measurement of CWD has been discussed extensively in the economic literature.

A substantial literature has estimated hedonic wage regression models to infer whether or not labor markets place a premium on jobs that involve disamenities. ${ }^{11}$ A hedonic wage regression is a Mincer-type wage regression (Mincer and Polachek, 1974), including disamenities as further control variables. One critique of this first approach to estimate CWD has been its failure to properly control for workers' heterogeneity. Brown (1981) overcomes this criticism using panel data. Applying a first difference approach, he finds however no systematic impact of amenities on wages in the US. Duncan and Holmlund (1983), using Swedish panel data and estimating a fixed effect model, find a significant effect only for stress and environmental conditions on wages.

A further issue regarding hedonic wage regressions is the abstraction from job search and labor market imperfections. Hwang et al. (1998) show theoretically that the standard hedonic wage regressions, which ignore the dynamic nature of the labor market, yield

\footnotetext{
${ }^{11}$ See Lucas (1977) for an early application of hedonic wage regressions in the US. In Germany, Lorenz and Wagner (1989) find that physical effort affects wages negatively, contrary to the predictions of the theory.
} 
evidence of compensation for the disamenities which might be underestimated or even have an incorrect sign. ${ }^{12}$

Here, I estimate a hedonic wage regression taking unobserved individual heterogeneity into consideration by applying the fixed-effect method, but bearing in mind that the estimated coefficients might be underestimated. Hence, the estimated prices mothers have to pay in order to avoid certain disamenities provide only a lower bound and the reduction of the child penalty might possibly be even stronger. The function to be estimated is as follows: ${ }^{13}$

$$
\begin{aligned}
& \mathrm{Y}_{\mathrm{it}}=\beta_{1} * \operatorname{Pre}_{\mathrm{it}}+\beta_{2} * \text { Birth }_{1 \mathrm{it}}+\beta_{3} * \text { Post }_{\mathrm{it}}+\gamma^{*} \text { Disamenities }_{\mathrm{it}}+\delta_{1} * \text { Turnover }_{\text {it }} \\
& +\delta_{2} * \text { Turnover }_{\mathrm{it}} * \text { Post }_{\mathrm{it}}+\eta * \mathrm{X}_{\mathrm{it}}+\mathrm{a}_{\mathrm{i}}+\mathrm{u}_{\mathrm{it}}
\end{aligned}
$$

The independent variable is the logarithm of the gross wage rate. As stated above, the hedonic wage regression is augmented by the disamenities, here the job characteristics that change around the first childbirth (see Section 4.2.1). I additionally control for turnover, which allows me to control for a loss in firm-specific human capital and further unreported changes in job characteristics due to a job change. Thus, I can disentangle the wage effect of particular disamenities from that of a general job change. Furthermore, including an interaction term between motherhood and turnover allows me to determine the wage effect of job turnover for women with and without children separately. Last, as in the event study, I include a set of dummies describing the periods around the first childbirth and additional control variables, represented by $\mathrm{X}_{\mathrm{it}}$.

Before turning to the estimation results, notice that the theory of CWD applies only to job characteristics that are unequivocally desired or avoided, such as the risk of injuries or hazards. Job features that are unanimously avoided are compensated by a wage increase. Job features that are neither liked nor disliked by all workers are not associated with an

\footnotetext{
${ }^{12}$ For this reason, Villanueva (2007) suggests an estimation method taking only the sample of job leavers into account. Owing to the small sample size, however, it is not possible to estimate CWD after the first birth using only the women who change their job voluntarily.

${ }^{13}$ Sample selection bias, tested for by applying the test by Wooldridge (1995) explained in 3.1.2, can be rejected.
} 
unambiguous wage change. Thus, if there is no unanimous aversion to a certain job feature, the fact alone that mothers might avoid it does not lead to a decrease in the wage.

\section{Results}

\subsection{Summary Statistics}

The sample consists of 2,814 women (12,640 observations) of which 1,989 are mothers. Table 3 gives an overview of the summary statistics of the sample. The first major difference between mothers and non-mothers is the percentage of women who have a partner. While more than $80 \%$ of mothers have a partner, almost $50 \%$ of the non-mothers are single. The non-mothers are also younger than the mothers (average age is 31 versus 35). This reflects to some extent the shortcoming of the sample that non-mothers could still become mothers after 2005. The mean age given at the first childbirth is 28 years, which is quite young compared to the current average in Germany (since 2000 it has risen above 29 years). This can be explained by the fact that the mean age when mothers give birth to their first child in our sample is an average of the last 20 years. Age at the first childbirth has risen substantially during the last decades. The sample also closely reflects the regional composition in Germany: around 65\% are West Germans and around 22\% are East Germans, the rest of the women are foreigners. On average women went to school for 11 years, which does not vary much between mothers and non-mothers.

\subsection{Regression results}

\subsubsection{Event study}

The first step of our analysis is to estimate whether not only wages but also non-wage aspects of women's jobs change once having a child. A summary of the statistics for all job characteristics can be found in Table 4 . 


\section{a. The Child Penalty}

Before looking at non-pecuniary job characteristics it is necessary to determine the child penalty for the sample of working women between ages 16 and 46 . The child penalty, measuring the effect of motherhood on wages, is estimated by applying fixed effects to equation (1), using as independent variable the logarithm of real gross wage rates. The logarithm of real gross wages for mothers is 2.35 , while for non-mothers it is 2.38 . Using the estimated coefficients of the Pre1 and the Post1 dummy, I can then calculate the child penalty $\left(\beta_{3}-\beta_{1}\right)$. In addition, equation (3) is estimated including the inverse mills ratio, which allows us to test for sample selection bias. ${ }^{14}$

As we can see in Table 5, empirical evidence of the child penalty is once again confirmed. After the first childbirth, mothers face a loss in gross wage rates of $19.4 \%$ with respect to their pre-birth wage rates (which corresponds to the difference between the coefficients of the Pre1, indicating that before childbirth wages for mothers are not significantly higher $(0.6 \%)$, and the Post1 variable, which indicates that wages drop significantly by $18.8 \%$ once mothers have their first child). The impact of all other control variables is as expected: mothers' wages rise with education and age, but at a declining rate. The suggested sample selection test, explained in Section 3.1.2., detects that the hypothesis of there being no sample selection cannot be rejected (the coefficient of the inverse mills ratio is not significant).

Recent findings by Kunze and Ejrnaes (2004) of a wage dip even before motherhood can be confirmed. In a regression where the years around the first childbirth are split (from five years prior to the first childbirth to six years afterwards (see Table 6), we can see that gross wages start to fall two years before the first childbirth. A significant fall, however, is only detected starting from the fourth year after childbirth. This might be explained by mothers' right to take maternity leave, which entitles mothers to a job guarantee during the

\footnotetext{
${ }^{14}$ The inverse mills ratio is calculated using the selection equation (2). Results of the probit estimation of the selection equation (2) are available upon request.
} 
first three years after giving birth. From year four onward, the child penalty grows stronger over the years, while, as we have seen before, LFP rises over the years after childbirth. So it seems that only women for whom the opportunity costs of not working are high continue to work around the time of first birth. The women who return later are penalized even more because of the loss in human capital associated with a longer career interruption. Hence, the child penalty arises and starts growing as soon as mothers' jobs are not protected by law.

\section{b. Job turnover}

Women might want to change their job when the current position does not allow for an easy combination of work and family. Looking at average turnover in Table 4, we can see that many job changes already take place before the first childbirth. This might indicate that women plan their career according to their fertility plans and, thus, provide an intuitive contradiction against fertility being endogenous to wage or employment shocks. Turnover, in general, but also split into changes of the employer and changes of the position within firms, are regressed on the set of dummies describing the periods around first childbirth and all other control variables described in Section 3.1.1. Results of a fixed-effect estimation applied to equation (3) can be seen in Table 7.

Motherhood seems to have a significant impact on job turnover: once a child is born, mothers seem to change jobs $4.3 \%$ more often than before. Most of the changes are changes to a new employer (3.1\%), while no significant movements happen within firms $(1 \%)$. A sample selection test has been conducted, but the hypothesis of there being no sample selection cannot be rejected, except for the case of changes within the same firm.

Looking at the results of a regression where the years around childbirth are split, we can see that turnover increases over the years after giving birth. ${ }^{15}$ This increase might indicate that women change slowly into work arrangements that allow for a better work-family balance.

\footnotetext{
${ }^{15}$ Regression results are available upon request.
} 
c. Non-pecuniary job characteristics

As previously mentioned, three different categories of non-pecuniary job characteristics suggested by the literature on CWD might be of specific interest for the combination of work and family: working schedule, workload and flexibility of the job. Before going into the descriptive statistics of these different job features, notice that most job characteristics can only be observed for a few years. Shift work and the variables for workload (stress, physical demand and bad working conditions) are observed for the years 1985, 1987, 1989, 1995 and 2001; work in the evening and during night only for the years 1990, 1995 and 2000; only in three years (1997, 1999 and 2002) women were asked if they work from home. In order to maximize the sample size, the following technique, suggested by Villanueva (2007), is applied to impute these job characteristics. A new variable, called job change, is created, which enables us to determine the years in which a woman holds the same job. Using this variable, the job characteristics reported for only certain years can be extended to all the years in which a woman retains the same job.

Let me now provide a short overview of the average characteristics of the jobs held by mothers and non-mothers (see table 4). In general, the contracts of non-mothers include more hours per week than that of mothers (37 hours versus 31 hours). The actual working hours (agreed hours plus overtime) of non-mothers exceed those of mothers even more (40 hours versus 33 hours). The presence of children also decreases the probability of working during inconvenient hours such as in the evening (14\% versus $11 \%)$ or at night $(12 \%$ versus $11 \%)$. It increases, however, the engagement in rotating shifts $(26 \%$ versus $30 \%)$, which might possibly allow for a better combination of career and family. Almost no women enjoy flexible working hours (not even 1\%). This reflects how regulated the German labor market is, or put more precisely, has been over the last 20 years. Nevertheless, more than $11 \%$ of the mothers and almost $8 \%$ of the non-mothers work from home. Mothers also live closer to their workplace $(15 \mathrm{~km}$ versus $11 \mathrm{~km})$, which allows them to save commuting time. This might be 
an important aspect, since time is a scarce resource for mothers. With respect to workload, mothers report worse conditions than non-mothers: $55 \%$ of non-mothers versus $58 \%$ of mothers consider their work stressful, while only $20 \%$ of non-mothers versus $28 \%$ of mothers see it as physically strenuous. Mothers may judge their work as more tiring owing to the double load of work and domestic activities. Mothers are also more likely to report bad working conditions (21 versus 18\%).

In order to see how motherhood affects these job characteristics, a fixed-effect method is applied to equation (1) regressing all non-pecuniary job features on the same set of control variables as before. Furthermore, I estimate equation (3), which includes the inverse mills ratio derived from the results of a probit estimation of equation (2). This allows me to test for sample selection bias and, if necessary, to correct for it. Estimation results of equation (3), using non-pecuniary characteristics as the dependent variables are shown in Table 8 .

The results of the event study show significant changes around the first childbirth for all three categories. As already seen in the descriptive statistics, women tend to work less after having a child. We can observe a strong and significant decrease in working hours after motherhood (-14.6 hours). In addition, mothers seem to avoid a working schedule outside the usual working hours ( 8 a.m. to 6 p.m.). In other words, they work less during the evening ($8.1 \%)$ and at night $(-5.6 \%)$. A further indication that mothers try to decrease the time away from home is the fact that the distance to the workplace decreases once a woman gives birth to her first child $(-1.3 \mathrm{~km})$. Mothers also seem to dislike a heavy workload. Once becoming a mother, their work tends to be significantly less stressful $(-10.2 \%)$ and offers better working conditions $(3.4 \%)$. The result for physical strain, however, indicates that mothers see their work as a greater burden than non-mothers (3.7\%). The double workload of job and domestic activities may explain this finding. Looking at the coefficients of the inverse mills ratio we can see that sample selection seems to affect the estimation results only in the case of working hours and night work. 
These findings provide evidence that certain non-pecuniary job features change around the first childbirth and hence indicate an aversion of mothers to these job characteristics. They also suggest that mothers might sacrifice income for fewer disamenities.

Looking at regressions where the years around the time of the first childbirth are further split (into five years before and six years after child-birth), the change in mothers' job characteristics around the arrival of their first child seems strategic. ${ }^{16}$ Several non-wage job characteristics, such as stress and bad working conditions begin to decrease already before the first childbirth. This provides an intuitive contradiction against the possible endogeneity of fertility, i.e. against the concern that wage and career opportunities might determine the decision to have a baby.

Having determined which job characteristics change around motherhood, and thus seem to be disliked by mothers, the next step is to estimate how much of wages mothers sacrifice in order to diminish these undesired working conditions. Thus in the next section, I present the results of a hedonic wage regression.

\subsubsection{Hedonic wage regression}

With knowledge about the job features that seem to be disliked by mothers, we can now estimate the price that mothers pay to avoid these undesired characteristics. From there, we can derive the child penalty by taking into account the wage premium that mothers sacrifice when avoiding certain unpleasant or family-unfriendly job features.

For this purpose, I estimate a hedonic wage regression, as represented in equation (4). In other words, I re-estimate the event study using the logarithm of the real gross wage rate as the dependent variable. As further control variables, I include all job characteristics that in Section 4.2.1 have been shown to change significantly around the first childbirth: actual hours

\footnotetext{
${ }^{16}$ Regression results available upon request.
} 
worked per week, night work, work in the evening, stress, physical demand, bad working conditions and, lastly, distance to the workplace. ${ }^{17}$

In the second step, I additionally control for job turnover (by including a dummy for job changes) and, in particular, for turnover of mothers (by including an interaction term between turnover and the dummy variable Post1). This might allow us to control for the wage effect of unreported changes in the work arrangement and the possible wage reduction due to a loss in firm-specific human capital. Table 9 shows the results for the variables of most interest.

Comparing the first and second columns shows that mothers are remunerated for exposure to certain non-pecuniary job characteristics. Both having a stressful job and bad working conditions increase the wage rate by $2.5 \%$. The results of the event study with respect to time are also reflected in the results of the hedonic wage regression, even if only at a $15 \%$ significance level; time seems to be a scarce and valuable resource for women after entering motherhood. One more hour of work per week requires a wage increase of $0.1 \%$, while working during the evening hours $(6-9 \mathrm{pm})$ requires almost $2 \%$. Every kilometer further from the workplace is also compensated by an increase in the wage rate: by $0.1 \%$. Including the unfavorable job features that are significantly reduced around first childbirth diminishes the child penalty by $8 \%$ (from $-19.4 \%$ to $-18 \%$ ). This may indicate the willingness of mothers to sacrifice some income to avoid certain disamenities.

The results of the fourth column show that when women change workplaces, they generally suffer a wage loss of $6 \%$, which increases to $8.3 \%$ once becoming a mother. This indicates that mothers might encounter more difficulties in finding a well-paid job, and thus might reflect some employer discrimination. It also implies that new working arrangements might involve fewer disamenities and thus a lower wage. The unexplained part of the child penalty is further decreased to a $17.8 \%$.

\footnotetext{
${ }^{17}$ Furthermore, I test for sample selection bias using the methodology described in Section 3.1.2. Since the null hypothesis of no sample selection bias cannot be rejected, a correction is not necessary.
} 
Looking at these results, we can see that taking into account job changes and selected disamenities decreases the child penalty by $8.3 \%$. Yet, the difference between the estimated 'raw' child penalty and the one accounting for disamenities is not significant at a $90 \%$ confidence interval. ${ }^{18}$ However, the results of hedonic wage regressions, as mentioned in Section 4.3, have to be interpreted carefully. As Hwang et al. (1998) pointed out, hedonic wage regressions might lead to down-ward biased coefficients. Hence, the estimated disamenities coefficients provide only a lower bound for the prices mothers have to pay in order to avoid certain disamenities. Also the actual wage loss mothers suffer when accepting a new work arrangement involving fewer disamenities might be higher than the one estimated. Thus, the results of the hedonic wage regression are suggestive of a CWD story; namely, lower wages of mothers reflect their preferences for a variety of non-wage job features. Mothers seem to sacrifice a significant wage fraction to decrease certain disamenities and thus the gap in wages due to motherhood shrinks.

\section{Conclusion}

The balance of career and family is a hot topic on the current political agenda. One indication that mothers still encounter barriers to success in the labor market is the child penalty - i.e. the fact that mothers earn lower wages than women without children. Even if several hypotheses about its sources have been explored, much of the gap remains unexplained. Recent studies have only partially exploited the hypothesis that women, once they have a baby, adjust their jobs in a way that they can combine work and family better, i.e. they choose a more family oriented wage/disamenities package.

This study contributes to the literature by investigating not only changes in wages, but also changes in several non-wage aspects of women's jobs once they become mothers. I additionally estimate how much of their wage mothers sacrifice in order to avoid certain non-

\footnotetext{
${ }^{18}$ The $90 \%$ confidence interval for the specification (3) is [-14.7;-20.9].
} 
pecuniary job characteristics. In other words, I investigate if the drop in wages around motherhood can be attributed to a compensating wage differential (CWD) story.

In order to assess this hypothesis, data from the German Socio-Economic Panel (GSOEP) is used. The GSOEP provides detailed information about personal attributes and job characteristics, with attention given to the wage as well as to several non-wage features of jobs. Its longitudinal nature allows us to compare women before and after first childbirth, and thus to study changes in women's preferences around this time.

Using a sample of women aged 16 to 46, an event study, corrected for selection into the labor force, is undertaken to analyze changes in wages, job turnover and several nonpecuniary job features around motherhood. The child penalty in this sample reaches almost $20 \%$ when comparing the gross wage rates of women before and after first childbirth. Besides increased job turnover, several job characteristics change around this time as well. A sharp decline can be observed in working hours (14.5 hours less), which can be explained by reduced overtime and more part-time contracts. Mothers also work less at inconvenient working hours (i.e. after 6 p.m. or at night, $8.1 \%$ and 5.6\% less, respectively). Furthermore, when becoming a mother a woman is more likely to have a job that is closer to her home $(1.3 \mathrm{~km}$ closer). This enables her to save some commuting time. Finally, the results suggest that mothers tend to avoid a heavy workload, such as stress (10.2\%) and bad working conditions $(3.4 \%)$.

The estimation results show that mothers are willing to sacrifice a significant fraction of their wages in order to avoid disamenities such as stress (they pay $2.4 \%$ of their wage), bad working conditions $(2.6 \%)$ and commuting time $(0.1 \%$ for $10 \mathrm{~km}$ less distance $)$. Job turnover is also associated with a wage loss $(8.3 \%)$, which might point towards the fact that mothers change jobs for working arrangements that offer fewer disamenities and thus lower wages. Including certain disamenities and a dummy for job turnover in the wage regression decreases 
the estimates of the child penalty by almost $10 \%$. These results indicate that some part of the wage penalty might be driven by a CWD, reflecting mothers' aversion to job disamenities.

Among the research on the child penalty, this study is the first to take a broad range of disamenities into consideration and test the hypothesis that the child penalty can be interpreted as a CWD, i.e. mothers trade wages for non-wage job aspects. It provides knowledge about the aversion of mothers to several non-pecuniary job aspects and the price they have to pay in order to avoid them. The findings provide evidence that mothers might be willing to sacrifice some of their income in order to better combine family and work - thus part of the child penalty might be attributed to a CWD. Besides their relevance to better identify the sources of the child penalty, the results of this study might be useful in improving the design of family policies targeted at the compatibility of family and work life.

\section{Bibliography}

Amuedo-Dorantes, C. and Kimmel, J. (2008); "New Evidence on the Motherhood Wage Gap", IZA Discussion Paper No.3662

Beblo, M. and Wolf, E. (2000); “ How much does a year off cost? Estimating the Wage Effects of Employment Breaks and Part-Time Periods" DP 00-69, ZEW

Beblo, M. and Wolf, E. (2002) “Wage penalties for Career Interruptions”; DP 02-45, ZEW

Beblo, M., Bender, S. and Wolf, E. (2004); "The wage effects of entering motherhood: A within firm matching approach"; ZEW and IAB, Mannheim

Becker, G. (1985): Human Capital, Effort, and the Sexual Division of Labor, Journal of Labor Economics, 3(1), pt.2, pp. S34-S58.

Bratti M., Del Bono E. and Vuri D. (2004); “New Mothers' Labour Force Participation in Italy: The Role of Job Characteristics"; IZA DP. No.1111

Brown (1981); "Equalizing differences in the Labor Market", The Quarterly Journal of Economics, Vol 94, No.1, p 113-134

DeLeire, T. and Levy, H. (2001); “Gender, Occupation choice and the risk of death"; NBER, Working Paper 8574 
Duncan and Holmlund (1983), "Was Adam Smith right after all: Another Test of the Theory of Compensating Wage Differentials”, Journal of Labour Economics Vol.1, No 4, 366-379

Dustmann, C. and Rochina Barrachina, M. (2000); "Selection Correction in Panel Data Models: An Application to Labour Supply and Wages"; Discussion Paper No. 162; IZA

Felfe, C. (2008); “Mothers' Marginal Willingness to Pay for Amenities”, mimeo

Harkness, S. and Waldfogel, J. (1999), "The family gap: evidence from seven industrialized countries"; CASE paper no.29 Centre for Analysis of Social Exclusion, London

Jimenez-Martín, S. (2006), "Strike outcomes and wage settlements", Labour, 20(4), 673-698

Joshi, H.; Paci, P. and Waldfogel, J. (1999): The Wages of Motherhood: Better or Worse? Cambridge Journal of Economics, 23(5), pp. 543-64.

Kunze, A. (2002); “The timing of Careers and Human Capital Depreciation"; Discussion Paper No. 509, IZA Bonn

Kunze, A. and Mette, E. (2004); "Wage Dips and Drops around first birth"; Discussion Paper. No. 1011, IZA, Bonn

Kyriadzidou, E. (1997); "Estimation of a Panel Data Sample Selection Model"; Econometrica, Vol.65, No. 6, 1335-1364

Lorenz and Wagner (1989); "Kompensierende Lohndifferentiale und geschlechtsspezifische Einkommensdiskriminierung"; In: K. Gerlach and O. Huebler (eds.) Effizienzlohntheorie, Individualeinkommen und Arbeitsplatzwechsel

Lundberg, S. and Rose, E. (2000); "Parenthood and the earnings of married men and women.”; Labour Economics, vol. 7, no.6, pp. 689-710

Mincer, J. and Polachek, S. (1974): Family Investment in Human Capital: Earnings of Women, Journal of Political Economy, 82(2), (supplement), pp. S76-S108.

Phipps, S., Burton, P. and Lethbridge, L. (2001); "In and out of Labour Market: Long-term Income Consequences of Child-Related Interruptions to Women's Paid Work", Canadian Journal of Economics, 34(2), pp. 411-429

Rosen, H. (1986) ; “The Theory of Equalizing Differences” In Handbook of Labor Economics Vol. 1, edited by O. Ashenfelter and R. Layard. Amsterdam. Elsevier.

Smith, A. (1776); "An Inquiry into the Nature and Causes of the Wealth of Nations"; The University of Chicago Press; Chicago 60637; Edition 1976

Villanueva E., (2007); "Estimating Compensating Wage Differentials Using Voluntary Job Changes: Evidence from Germany", Industrial and Labor Relations Review, Vol. 60, No. 4,

Waldfogel, J. (1994);'Women Working for Less. Family Status and Women's Pay in the US and UK"; Working Paper \#D-94-1, Malcom Wiener Center for Social Policy, Cambridge 
Waldfogel, J. (1997); "The effect of children on women's wages"; American Sociological Review, Vol. 62, pp. 209-217

Waldfogel, J. (1998a) "Understanding the family gap in pay for women with children"; Journal of Economic perspectives, Vol. 121998

Waldfogel, J. (1998b); "The family gap for young women in the US and GB: can maternity leave make a difference?”; Journal of Labour Economics, vol. 16, no.3, pp.505-545

Wooldridge, J. (1995); „Selection corrections for panel data models under conditional mean independence assumptions“; Journal of Econometrics 68, 115 - 132

Wooldridge, J. and Semykina, A. (2005); „Estimating Panel Data Models in the Presence of Endogeneity and Selection: Theory and Application“; Michigan State University

\section{Tables and Figures}

Table 1: Definition and Construction of dependent variables

\begin{tabular}{l|l} 
Name of variable & Definition \& Construction \\
\hline Pecuniary Aspect & \\
\hline Ln of real gross wage rate & $\begin{array}{l}\text { Ln of ((monthly gross income/ weekly contracted working } \\
\text { hours)*31/7) }\end{array}$ \\
\hline Non Pecuniary Aspects & \\
\hline 1.Time & $\begin{array}{l}\text { Weekly working hours incl. overtime, but not illness or } \\
\text { holidays }\end{array}$ \\
\hline Actual hours worked & Binary variable indicating if worked between $6 \mathrm{pm}-10 \mathrm{pm}$ \\
\hline Work in the evening* & Binary variable indicating if worked after 10pm \\
\hline Night work* & Binary variable indicating if shift work \\
\hline Shift work* & Binary variable indicating if job is stressful. \\
\hline 2.Workload & Binary variable indicating if job is physically demanding. \\
\hline Stress at work* & $\begin{array}{l}\text { Binary variable indicating if worker is exposed to bad working } \\
\text { conditions such as heat, gases, etc. }\end{array}$ \\
\hline Physical Demand of job* \\
\hline Bad working conditions*
\end{tabular}


Table 2: Labour Force Participation

\begin{tabular}{|c|c|}
\hline & Mean labor force participation \\
\hline 5 years pre birth & $79.58 \%$ \\
\hline 4 years pre birth & $81.34 \%$ \\
\hline 3 years pre birth & $82.96 \%$ \\
\hline 2 years pre birth & $82.13 \%$ \\
\hline 1 year pre birth & $80.51 \%$ \\
\hline Birth1 & $34.45 \%$ \\
\hline 1 year post birth & $24.64 \%$ \\
\hline 2 years post birth & $35.61 \%$ \\
\hline 3 years post birth & $40.28 \%$ \\
\hline 4 years post birth & $45.20 \%$ \\
\hline 5 years post birth & $48.02 \%$ \\
\hline 6 years post birth & $52.60 \%$ \\
\hline 18 years post birth & $63.56 \%$ \\
\hline
\end{tabular}


Table 3: Summary statistic of the sample

\begin{tabular}{l|ccccc} 
Variable & Obs & Mean & Std. Dev. & Min & Max \\
\hline Age & 12460 & 34.2511 & 7.4317 & 17 & 46 \\
Partner & 12460 & 0.7387 & 0.4394 & 0 & 1 \\
Years of education & 12460 & 11.2665 & 3.7516 & 0 & 18 \\
West & 12460 & 0.6543 & 0.4756 & 0 & 1 \\
East & 12460 & 0.2206 & 0.4147 & 0 & 1 \\
Foreigner & 12460 & 0.1251 & 0.3309 & 0 & 1 \\
Pre & 12460 & 0.1283 & 0.3345 & 0 & 1 \\
Birth & 12460 & 0.0142 & 0.1183 & 0 & 1 \\
Post & 12460 & 0.5425 & 0.4982 & 0 & 1 \\
\hline
\end{tabular}

Note: The underlying sample includes all women in their fertile ages defined as 16-46 who are having their first child as of 2006 and are working

\begin{tabular}{l|ccccc} 
& Nonmother & Mothers & Pre1 & Birth1 & Post1 \\
\hline Observations & 3925 & 8535 & 1599 & 177 & 6759 \\
\# of individuals & 825 & 1989 & 487 & 177 & 1666 \\
Age & 31.25 & 35.63 & 25.40 & 28.24 & 38.24 \\
Partner & 0.53 & 0.84 & 0.69 & 0.86 & 0.87 \\
Education (years) & 11.28 & 11.26 & 10.72 & 11.12 & 11.39 \\
West & 0.75 & 0.61 & 0.74 & 0.74 & 0.58 \\
East & 0.12 & 0.27 & 0.14 & 0.16 & 0.30 \\
Foreigner & 0.13 & 0.12 & 0.12 & 0.10 & 0.12 \\
\hline
\end{tabular}

Note: The underlying sample includes all women in their fertile ages defined as 16-46 who are having their first child as of 2006 and are working 
Table 4: Descriptive dependent variables

\begin{tabular}{l|ccccc} 
& Obs & Mean & Std. Dev. & Min & Max \\
\hline Ln of real gross wage rate & 12460 & 2.3612 & 0.4568 & -0.0440 & 3.7980 \\
Actual working hours/week & 12460 & 35.4273 & 10.1228 & 3 & 70 \\
Agreed working hours/week & 12460 & 33.2246 & 8.9375 & 4 & 48 \\
Overtime & 12460 & 1.5092 & 2.6124 & 0 & 28 \\
Shift work & 12460 & 0.2690 & 0.4435 & 0 & 1 \\
Night work & 12460 & 0.1103 & 0.3132 & 0 & 1 \\
Work in the evening & 12460 & 0.1334 & 0.3400 & 0 & 1 \\
Stressful job & 12460 & 0.5676 & 0.4954 & 0 & 1 \\
Physically demanding job & 12452 & 0.2571 & 0.4371 & 0 & 1 \\
Bad working conditions & 12460 & 0.2030 & 0.4022 & 0 & 1 \\
Flexible hours & 12460 & 0.0046 & 0.0675 & 0 & 1 \\
Work from home & 12460 & 0.0975 & 0.2967 & 0 & 1 \\
Distance to workplace & 12460 & 12.4070 & 13.4749 & 0 & 120 \\
Job Change & 12460 & 0.0517 & 0.2214 & 0 & 1 \\
New Employer & 12460 & 0.0388 & 0.1932 & 0 & 1 \\
Within firm change & 12460 & 0.0128 & 0.1126 & 0 & 1 \\
\hline
\end{tabular}

Note: The underlying sample includes all women in their fertile ages defined as 16-46 who are having their first child as of 2006 and are working

\begin{tabular}{l|ccccc} 
& Nonmother & Mothers & Pre1 & Birth1 & Post1 \\
\hline Ln of real gross wage rate & 2.38 & 2.35 & 2.16 & 2.35 & 2.40 \\
Actual hours/week & 39.74 & 33.45 & 39.84 & 37.88 & 31.82 \\
Agreed hours/week & 37.07 & 31.46 & 37.97 & 35.98 & 29.79 \\
Overtime & 1.82 & 1.36 & 1.45 & 0.92 & 1.36 \\
Shift work & 0.30 & 0.26 & 0.18 & 0.24 & 0.27 \\
Night work & 0.12 & 0.11 & 0.08 & 0.12 & 0.11 \\
Work in the evening & 0.11 & 0.14 & 0.15 & 0.19 & 0.14 \\
Stressful job & 0.55 & 0.58 & 0.76 & 0.66 & 0.53 \\
Physically demanding job & 0.20 & 0.28 & 0.34 & 0.28 & 0.27 \\
Bad working conditions & 0.18 & 0.21 & 0.30 & 0.21 & 0.19 \\
Flexible hours & 0.01 & 0.00 & 0.01 & 0.01 & 0.00 \\
Work from home & 0.07 & 0.11 & 0.12 & 0.12 & 0.11 \\
Distance to workplace & 14.68 & 11.36 & 13.57 & 14.45 & 10.76 \\
Job Change & 0.06 & 0.05 & 0.12 & 0.02 & 0.03 \\
New Employer & 0.05 & 0.04 & 0.09 & 0.01 & 0.03 \\
Within firm change & 0.02 & 0.01 & 0.03 & 0.01 & 0.01 \\
\hline
\end{tabular}

Note: The underlying sample includes all women in their fertile ages defined as 16-46 who are having their first child as of 2006 and are working 
Table 5: Child Penalty - Results of fixed effect regressions

\begin{tabular}{|c|c|c|}
\hline & Ln real gross wage rate & Ln real gross wage rate \\
\hline Pre1 & $\begin{array}{l}0.006 \\
(0.29)\end{array}$ & $\begin{array}{l}0.006 \\
(0.29)\end{array}$ \\
\hline Post1 & $\begin{array}{c}-0.188 \\
(8.60)^{* *}\end{array}$ & $\begin{array}{c}-0.188 \\
(8.60)^{* *}\end{array}$ \\
\hline Child Penalty & $\begin{array}{c}-0.194 \\
(12.90)^{* *}\end{array}$ & $\begin{array}{c}-0.194 \\
(12.90)^{* *}\end{array}$ \\
\hline Mills ratio & - & $\begin{array}{l}-0.008 \\
(0.24)\end{array}$ \\
\hline Partner & $\begin{array}{l}0.019 \\
(1.90)\end{array}$ & $\begin{array}{l}0.019 \\
(1.92)\end{array}$ \\
\hline Years of education & $\begin{array}{c}0.009 \\
(2.94)^{* *}\end{array}$ & $\begin{array}{c}0.008 \\
(2.81)^{* *}\end{array}$ \\
\hline Age & $\begin{array}{c}0.18 \\
(42.91)^{* *}\end{array}$ & $\begin{array}{c}0.18 \\
(40.89)^{* *}\end{array}$ \\
\hline Age squared & $\begin{array}{c}-0.002 \\
(34.19)^{* *}\end{array}$ & $\begin{array}{c}-0.002 \\
(33.58)^{* *}\end{array}$ \\
\hline Constant & $\begin{array}{c}-1.281 \\
(16.79)^{* *}\end{array}$ & $\begin{array}{c}-1.268 \\
(13.67)^{* *}\end{array}$ \\
\hline Observations & 12460 & 12460 \\
\hline Number Fixed ID & 2814 & 2814 \\
\hline R-squared & 0.37 & 0.37 \\
\hline
\end{tabular}


Table 6: Child penalty over the years - Results of fixed effect regressions

\begin{tabular}{|c|c|}
\hline & Ln of real gross wage rate \\
\hline \multirow[t]{2}{*}{ Yr5prebirth } & 0.042 \\
\hline & $(1.70)$ \\
\hline \multirow[t]{2}{*}{ Yr4prebirth } & 0.078 \\
\hline & $(3.23)^{* *}$ \\
\hline \multirow[t]{2}{*}{ Yr3prebirth } & 0.089 \\
\hline & $(3.70)^{* *}$ \\
\hline \multirow[t]{2}{*}{ Yr2prebirth } & 0.081 \\
\hline & $(3.24)^{* *}$ \\
\hline \multirow[t]{2}{*}{ Yr1prebirth } & 0.079 \\
\hline & $(3.07)^{* *}$ \\
\hline \multirow[t]{2}{*}{ Birth1 } & 0.069 \\
\hline & $(2.31)^{*}$ \\
\hline \multirow[t]{2}{*}{ Yr1postbirth } & 0.017 \\
\hline & $(0.47)$ \\
\hline \multirow[t]{2}{*}{ Yr2postbirth } & -0.037 \\
\hline & $(1.07)$ \\
\hline \multirow[t]{2}{*}{ Yr3postbirth } & -0.022 \\
\hline & $(0.63)$ \\
\hline \multirow[t]{2}{*}{ Yr4postbirth } & -0.086 \\
\hline & $(2.45)^{*}$ \\
\hline \multirow[t]{2}{*}{ Yr5postbirth } & -0.113 \\
\hline & $(3.11)^{* *}$ \\
\hline \multirow[t]{2}{*}{ Yr6postbirth } & -0.131 \\
\hline & $(3.59)^{* *}$ \\
\hline \multirow[t]{2}{*}{ Post6 } & -0.211 \\
\hline & $(5.72)^{* *}$ \\
\hline \multirow[t]{2}{*}{ Constant } & -0.84 \\
\hline & $(6.14)^{* *}$ \\
\hline Observations & 8535 \\
\hline Number of Fixed ID & 1989 \\
\hline R-squared & 0.32 \\
\hline
\end{tabular}

T-statistics are reported in brackets below every coefficient

Set of control variables included as well having a partner, age, age squared, years of education, and set of year dummies for 1985-2005 
Table 7: Changes in turnover around motherhood - Results of fixed effect regressions

\begin{tabular}{|c|c|c|c|}
\hline & Turnover & $\begin{array}{c}\text { New } \\
\text { Employer }\end{array}$ & Within Firm \\
\hline \multirow[t]{2}{*}{ Pre } & 0.042 & 0.048 & -0.006 \\
\hline & $(2.19)^{*}$ & $(2.84)^{* *}$ & $(0.56)$ \\
\hline \multirow[t]{2}{*}{ Post } & 0.085 & 0.079 & 0.005 \\
\hline & $(4.24)^{* *}$ & $(4.52)^{* *}$ & $(0.49)$ \\
\hline \multirow[t]{2}{*}{ Change } & 0.043 & 0.031 & 0.011 \\
\hline & $(3.14)^{* * *}$ & $(2.60)^{* * *}$ & $(1.56)$ \\
\hline \multirow[t]{2}{*}{ Mills ratio } & -0.035 & -0.004 & -0.031 \\
\hline & $(-1.179)$ & $(-0.169)$ & $(-1.880)^{*}$ \\
\hline \multirow[t]{2}{*}{ Partner } & -0.004 & 0.001 & -0.006 \\
\hline & $(-0.493)$ & -0.148 & $(-1.136)$ \\
\hline \multirow[t]{2}{*}{ Education } & -0.001 & 0.002 & -0.003 \\
\hline & $(0.378)$ & $(0.909)$ & $(-2.147)^{* *}$ \\
\hline \multirow[t]{2}{*}{ Age } & -0.047 & -0.039 & -0.007 \\
\hline & $(-11.84) * * *$ & $(-11.37) * * *$ & $(-3.376) * * *$ \\
\hline \multirow[t]{2}{*}{ Age squared } & 0.001 & 0.001 & 0.000 \\
\hline & $(9.912) * * *$ & $(10.04) * * *$ & $(1.994) * *$ \\
\hline \multirow[t]{2}{*}{ Constant } & 0.936 & 0.694 & 0.242 \\
\hline & $(11.08) * * *$ & $(9.353) * * *$ & $(5.228) * * *$ \\
\hline Observations & 12460 & 12460 & 12460 \\
\hline \# of individuals & 2814 & 2814 & 2814 \\
\hline R-squared & 0.121 & 0.1 & 0.025 \\
\hline
\end{tabular}

T-statistics are reported in brackets below every coefficient, $*$ indicates that the coefficient is significant at a $5 \%$ level and $* *$ at a $1 \%$ level Set of control variables included furthermore a set of year dummies for 1985-2005 


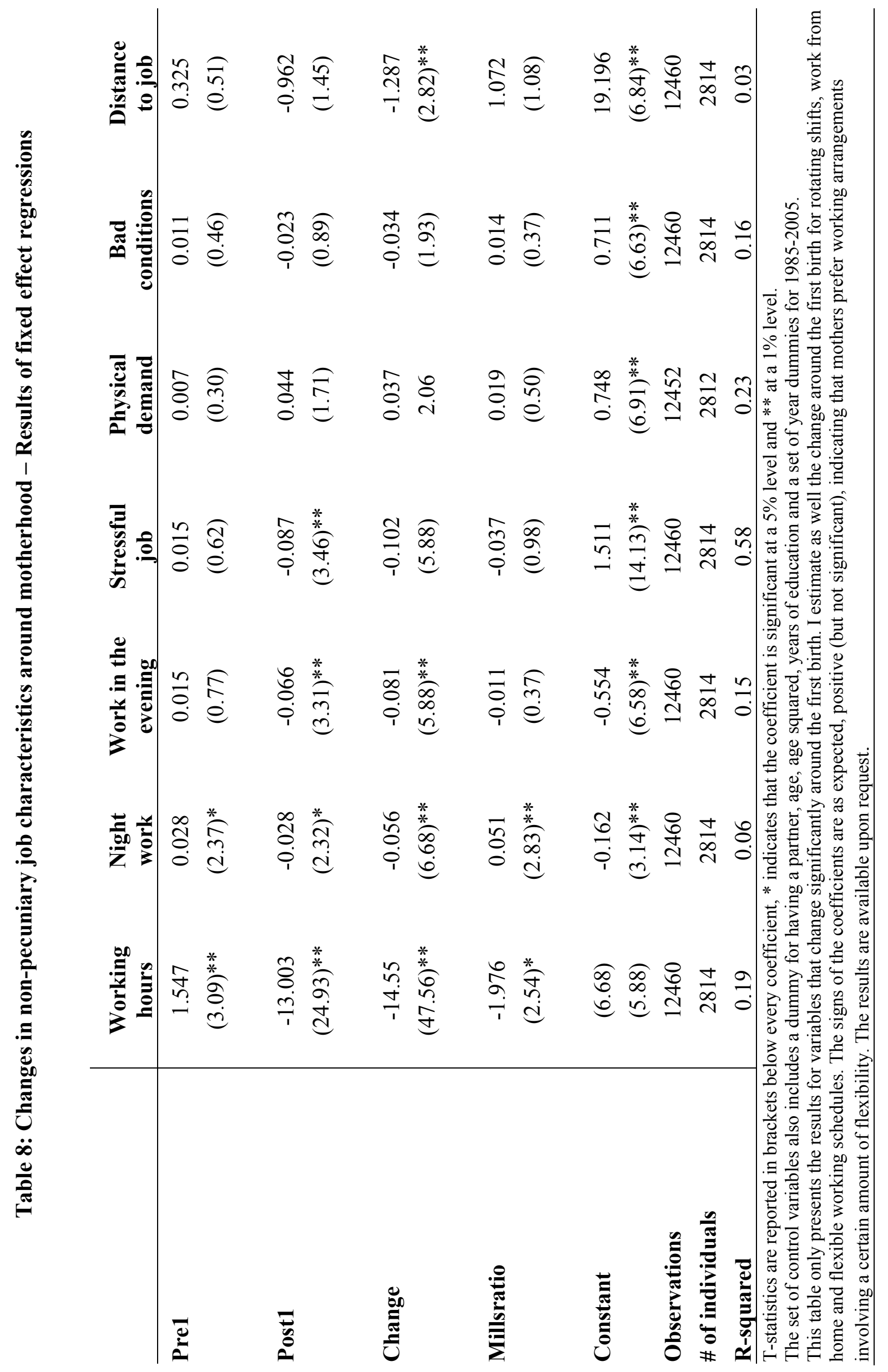


Table 9: Hedonic Wage Regression - Results of fixed effect regressions

\begin{tabular}{|c|c|c|c|c|}
\hline & $\begin{array}{c}\text { Ln real } \\
\text { gross wage }\end{array}$ & $\begin{array}{c}\text { Ln real } \\
\text { gross wage }\end{array}$ & $\begin{array}{c}\text { Ln real } \\
\text { grosswage }\end{array}$ & $\begin{array}{c}\text { Ln real } \\
\text { gross wage }\end{array}$ \\
\hline \multirow[t]{2}{*}{ Pre } & 0.006 & 0.004 & 0.007 & 0.007 \\
\hline & $(0.29)$ & $(0.21)$ & $(0.35)$ & $(0.32)$ \\
\hline \multirow[t]{2}{*}{ Post } & -0.188 & -0.176 & -0.171 & -0.171 \\
\hline & $(8.60)^{* *}$ & $(7.79)^{* *}$ & $(7.59)^{* *}$ & $(7.57)^{* *}$ \\
\hline \multirow[t]{2}{*}{ Child Penalty } & -0.194 & -0.18 & -0.178 & -0.178 \\
\hline & $(12.9)^{* *}$ & $(11.05)^{* *}$ & $(10.95)^{* *}$ & $(10.87)^{* *}$ \\
\hline \multirow[t]{2}{*}{ Working hours } & - & 0.001 & 0.001 & 0.001 \\
\hline & - & $(1.42)$ & $(1.24)$ & $(1.24)$ \\
\hline \multirow[t]{2}{*}{ Night work } & - & -0.018 & -0.017 & -0.017 \\
\hline & - & $(0.90)$ & $(0.86)$ & $(0.87)$ \\
\hline \multirow[t]{2}{*}{ Work in evening } & - & 0.018 & 0.02 & 0.02 \\
\hline & - & $(1.50)$ & $(1.63)$ & $(1.63)$ \\
\hline \multirow[t]{2}{*}{ Stress } & - & 0.024 & 0.024 & 0.024 \\
\hline & - & $(2.71)^{* *}$ & $(2.73)^{* *}$ & $(2.74)^{* *}$ \\
\hline \multirow[t]{2}{*}{ Physical demand } & - & 0.002 & 0.002 & 0.002 \\
\hline & - & $(0.20)$ & $(0.19)$ & $(0.19)$ \\
\hline \multirow[t]{2}{*}{ Bad conditions } & - & 0.026 & 0.025 & 0.025 \\
\hline & - & $(2.78)^{* *}$ & $(2.72)^{* *}$ & $(2.72)^{* *}$ \\
\hline \multirow[t]{2}{*}{ Distance } & - & 0.001 & 0.001 & 0.001 \\
\hline & - & $(3.15)^{* *}$ & $(3.33)^{* *}$ & $(3.34)^{* *}$ \\
\hline \multirow[t]{2}{*}{ Job change } & - & - & -0.068 & -0.06 \\
\hline & - & - & $(6.06)^{* *}$ & $(4.42)^{* *}$ \\
\hline \multirow[t]{2}{*}{ Job change* post } & - & - & - & -0.023 \\
\hline & - & - & - & $(1.03)$ \\
\hline \multirow[t]{2}{*}{ Constant } & -1.281 & -1.375 & -1.312 & -1.307 \\
\hline & $(16.79)^{* *}$ & $(17.12)^{* *}$ & $(16.23)^{* *}$ & $(13.44)^{* *}$ \\
\hline Observations & 12460 & 12460 & 12460 & 12460 \\
\hline \# of individuals & 2814 & 2814 & 2814 & 2814 \\
\hline R-squared & 0.37 & 0.37 & 0.37 & 0.37 \\
\hline
\end{tabular}

I include as well age, age squared, marital status, years of education, origin and a set of year dummies for 1985-2005.

T-statistics are reported in brackets, * indicates that the coefficient is significant at a $5 \%$ level and $* *$ at a $1 \%$ level 